\title{
Somatotype differences between mapuche and non- mapuche children aged 10 to 12 years living in the province of cautín-araucanía
}

\begin{abstract}
The studies of the somatotype allow us to know the quantified description of the morphological configuration of the individual, through endomorphy, mesomorphy and ectomorphy. Due to the acquisition of new eating habits along with a greater sedentarism in the child and adolescent population, it has been speculated that they have generated modifications in the morpho functional structure. This therefore, has encouraged a study that allows to determine the difference between the somatotype of the Mapuche children and the non Mapuche that inhabit the Province of Cautín, IX region of Chile. The subjects who participated in this study were 350 healthy children with a mean age of $11 \pm 1$ years of age, height of $140.5 \pm 4.7 \mathrm{~cm}$ and a weight of $39.5 \pm 5 \mathrm{~kg}$. All anthropometric measures were based on the protocol of the International Society for the Development of Cineanthropometry (ISAK). According to somatotype calculations. The following classifications were present: Group 10years old; Endomorph-mesomorph, 11years, age group, endomorph-mesomorph, 12 years, age group, and mesomorph-endomorph. The results indicate that the 10 -year-old Mapuche children had lower values of endomorphy and higher values for mesomorphy $(\mathrm{p} \leq 0.01)$ than non-Mapuche children. The 11year-old Mapuche children had lower values of endomorphy and higher values for mesomorphy $(\mathrm{p} \leq 0.01)$, compared to nonMapuche children. The 12year-old Mapuche children had lower values of endomorphy and mesomorphy $(\mathrm{p} \leq 0.05)$ than non-Mapuche children. In conclusion, the Mapuche schoolchildren present a mesomorphic predominance, however, non-Mapuche children present predominance of the endomorphic component.
\end{abstract}

Volume 4 Issue I - 2017

\author{
José Bruneau Cháveza \\ 'Physical Education Pedagogy, Universidad Autónoma de Chile, \\ Chile \\ ${ }^{2}$ English Pedagogy, Universidad Autónoma de Chile, Chile
}

Correspondence: José Gastón Bruneau Chávez,Victoria Klock Devaudb, Physical Education Pedagogy, English pedagogy, Faculty of Education, Universidad Autónoma de Chile, Av. Alemania 01090, Chile, Tel 56452895I20,

Email jose.bruneau@uautonoma.c

Received: June 20, 2017 | Published: July 17, 2017

Keywords: somatotype, mapuche ethnicity, mesomorphy, endomorphy

\section{Introduction}

The evaluation of the human body is often expressed in quantitative terms; the somatotype allows an evaluation of the morphology and characteristics of the human body as a whole. There are several methods available for determining the composition of the human body. The Heath-Carter anthropometric method is most commonly used. ${ }^{1-3} \mathrm{~A}$ number of investigations in the international context have identified differences in somatotype among different ethnic groups in Australia, ${ }^{4}$ New Zealand ${ }^{5}$ and the United Kingdom. ${ }^{6}$ In Chile, few studies have been developed tending to present proposals of normality and most them have been referred to subjects of the national urban sector. Nevertheless, the interest to study the children belonging to our original ethnic groups, located in different parts of the country (Aimaras, Pascuenses, Huilliches, Mapuche) has been somewhat excluded. Studies in this regard show that there are differences between races and sex $; ;^{7,8}$ In the city of Valparaiso (Chile), after a study carried out by Almagia et al., ${ }^{9}$ it was concluded that in this locality the women marked an important predominance towards the endomorphy regarding men; this city presents different somatotype classifications in its population.

The somatotype provides useful information to characterize the physical changes during the life cycle, allowing comparisons between the relative forms of genders. Specific values of the somatotype and its components have been correlated in different pathologies, breast cancer, heart disease, scoliosis, obesity and osteoporosis..$^{10}$ According to Almagía et al. ${ }^{9}$ to determine the growth and nutritional status of the population, weight and height variables are not enough, if they are not accompanied by anthropometric parameters such as somatotype. We present a cross-sectional observational study in which two distinct groups based on the Mapuche and non-Mapuche ethnic groups are established.

\section{Methods}

The population was constituted by all the school population belonging to the second basic cycle of public schools of the Province of Cautín. The sample was selected by simple probabilistic sampling, randomly selecting 20 children from each of the public schools selected by tombola. For the study of the somatotype, random sampling made the selection of the sample. The size of it was previously calculated using a computer program with a confidence level of $95 \%$ (STAT CALC of the EPI INFO V.6.0 package). The sample size was of 350 students. Therefore, we worked with a total sample of 160 children of Mapuche descent and 190 non-Mapuche students from schools in the Province of Cautín.

The present study had the informed consent of the families of the children and was developed following the Declaration of Helsinki regarding work with human beings. The calculation of somatotype was performed using the equations proposed by Carter \& Heath. ${ }^{2}$ In addition, the distance between somatotypes of Mapuche vs nonMapuche in the somatocarta (distance between two somato points) was determined through Somatotype Dispersion Distance (DDS), calculated by Hebbelinck method. ${ }^{11}$ A DDS value greater than 2 indicates that there are significant differences between both groups. 
The students were evaluated in their respective educational centers. For the estimation of the Somatotype, the Heath-Carter method was applied; the data were recorded on the anthropometric sheet where basic data such as weight-height were recorded. Rosscraft (Metallic) anthropometric tape, the perimeter of contracted arm and calf was evaluated the humeral and femoral diameters were measured with the short branch anthropometer Rosscraft. The triceps, subscapular, supraspinal, and calf skin folds were measured with a Harpenden plicometer. To determine the body weight, a SECA model scale with a precision of $0.1 \mathrm{~kg}$ was used. Size was evaluated using a SECA model meter (Vogel \& HalkeGmbH \& CO.kg, Hamburg, Germany). The evaluation was made using techniques and standards described by I.S.A.K.

\section{Somatotype}

The rating scale and characteristics of the somatotype was described by Carter, the somatotype can be characterized by values that are qualitative and quantitative, these are presented in ranges 1 to $2 \frac{1}{2}$ (low), 3 to 5 (moderate), $51 / 2$ to 7 (high), $71 / 2$ to $8 \frac{1}{2}$ (extreme).

\section{Analysis of data}

Statistical analyzes were performed using Microsoft Excel version 7.0 for preliminary data emptying. For the statistical treatment, the SPSS software version 20.0 was used (SPSS Inc. Chicago), setting the minimum of significance at $5 \%$. Values are presented as frequencies in the categorical variable to be analyzed (somatotype). The normality of the distribution of this variable was studied by the Kolmorov Smirnov test. In relation to the analysis of the differences in the proportions of the somatotype object variable, the chi-square test was used.

Through the Somatotype Dispersion Distance (DDS), the distance between two somatotypes inside or outside the somatocarta (distance between two somatopoints) is determined. That is, it compares two somatotypes based on the coordinates (numerical values of $\mathrm{X}$ and Y).$^{12}$ Its equation originated by calculating the distance between two points, being hardly modified by what characterizes the relationship between the units $\mathrm{x}$ and $\mathrm{y}$, which is the cubic root. ${ }^{13}$

$$
D D S=\sqrt{3\left(x_{1}-x_{2}\right)^{2}+\left(y_{1}-y_{2}\right)^{2}}
$$

Where

\section{DDS: Dispersion distance of somatotype}

$\sqrt{ } 3$ : Constant that transforms units $\mathrm{x}$ into unit

$\mathrm{x}_{1} \mathrm{y}_{1}$ : Coordinates of the somatotype studied

$\mathrm{x}_{2} \mathrm{y}_{2}$ : Coordinates of the reference somatotype $=$ mean

The DDS allows to verify the distance between a studied somatotype. ${ }^{11}$ The considered standard or reference for the distance it was arbitrarily established with a statistically significant at $\mathrm{p}<0.05(95 \%$ confidence interval) when DDS was equal to or higher than 2 .

In addition, the distance between somatotypes of Mapuche vs nonMapuche in the somatocarta (distance between two somatopoints) was determined through Somatotype Dispersion Distance (DDS), calculated by Hebbelinck method. ${ }^{11}$ A DDS value greater than 2 indicates that there are significant differences between the two groups.

\section{Results}

The 10year-old Mapuche children had significantly lower values

in the endomorphic component than the non-Mapuche ( $4.4 \pm 0.4$ versus $5.1 \pm 0.5 \mathrm{P} \leq 0.01)$. In the mesomorphic component, non-Mapuche children recorded a higher value than the Mapuche ( $4.0 \pm 0.4$ vs $3.6 \pm 0.4$ $\mathrm{P} \leq 0.01)$. In the ectomorphic component, the Mapuche group showed higher values than the non-Mapuche $(2.5 \pm 0.5$ vs $2.2 \pm 0.6, \mathrm{P} \leq 0.01)$, Table 1. Despite the observed differences, the somatotype classifies both Mapuche and non-Mapuche children as "endomesomorphs". As for the somatotopic dispersion distance, it achieves a value of 2.2 (Figure 1), indicating that there is a significant difference between the somatotypes of the Two groups, being greater than 2 .

Table I Somatotype in IOyear-old Mapuche and non-Mapuche children

\begin{tabular}{llll}
\hline & Endomorphy & Mesomorphy & Ectomorphy \\
\hline Mapuche & 4.4 & 4 & 2.5 \\
No-Mapuche & $5.1^{* *}$ & $3.6 * *$ & $2.2^{* *}$
\end{tabular}

$* * p \leq 0.01$

\section{somatocarta}

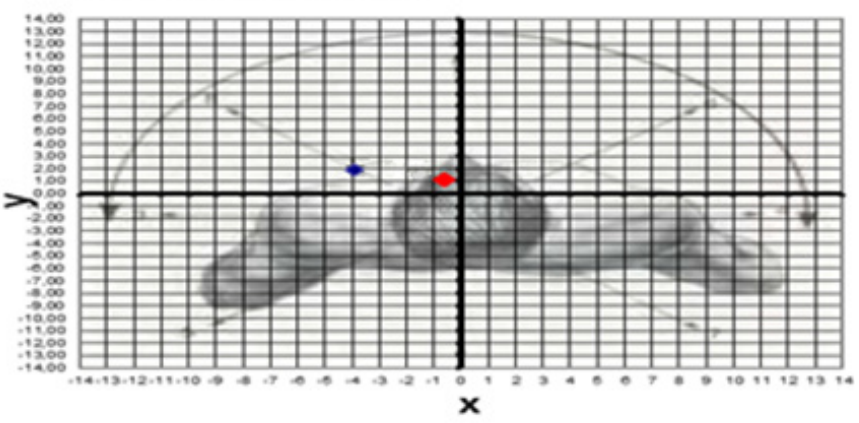

Figure I Somatotipic Dispersion Distance (SDD)"' DDS, 2.2; $\mathrm{p} \leq 0.05$. Mapuche; Non-Mapuche

Mapuche children aged 11years had significantly lower values in the endomorph component when compared to non-Mapuche children $(3.8 \pm 0.5$ vs $4.3 \pm 0.7 \mathrm{P} \leq 0.05)$. The mesomorphic component in the Mapuche group showed a higher value than in the non-Mapuche group (4.1 \pm 0.4 vs $3.9 \pm 0.6 \mathrm{P} \leq 0.05)$. The ectomorph component in the Mapuche group showed a higher value than in the non-Mapuche group $(2 \pm 0.5$ vs $2.3 \pm 0.8 \mathrm{P} \leq 0.05)$, Table 2 . Therefore, the Mapuche group is classified as mesoendomorph and the non-Mapuche group as endomesomorph, resulting in significantly different endomorphic, mesomorphic and ectomorphic values for both groups. As for the somatotopic dispersion distance (DDS), it achieves a value of 2, 03 (Figure 2), indicating that there are no significant differences between Mapuche and non-Mapuche somatotypes.

The 12year-old Mapuche children had significantly lower values in the endomorph component compared to the non-Mapuche (3.9 \pm 0.9 vs $4.1 \pm 0.7 \mathrm{P} \leq 0.01)$. In the mesomorphic component the Mapuche group showed a lower value than the non-Mapuche $(4.1 \pm 0.6$ vs $4.3 \pm 0.6 \mathrm{P} \leq 0.01)$. In the ectomorphic component the Mapuche group showed a lower value than the non-Mapuche $(2 \pm 0.5$ vs $2.4 \pm 0.6 \mathrm{P} \leq 0.05)$, Table 3 .

Therefore, the Mapuche are classified as mesoendomorphs and non-Mapuche as endomesomorphs, with endomorphic, mesomorphic and ectomorphic values being significantly different for both groups. As for the somatotopic dispersion distance (DDS), it achieves a value of 2.43 (Figure 3), indicating that there is a significant difference between the somatotypes of the two groups. 
Table 2 Somatotype in I lyear-old Mapuche and non-Mapuche children

\begin{tabular}{llll}
\hline & Endomorphy & Mesomorphy & Ectomorphy \\
\hline Mapuche & 3.8 & 4.1 & 2 \\
Non-Mapuche & $4.3^{*}$ & $3.9 *$ & $2.3^{*}$
\end{tabular}

$*_{p} \leq 0.05$

\section{somatocarta}

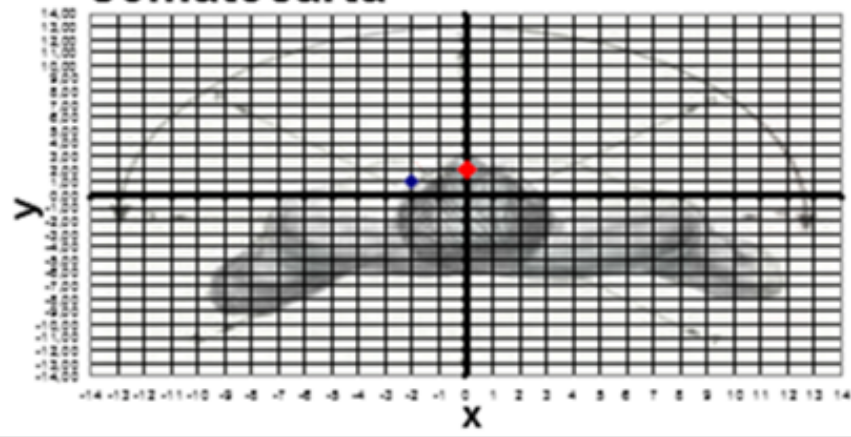

Figure 2 Somatotype in I lyear-old Mapuche and non-Mapuche children." DDS, 2.03; $P \leq 0.05$.

Mapuche; Non-Mapuche

Table 3 Somatotype in 12year-old Mapuche and non-Mapuche children

\begin{tabular}{llll}
\hline & Endomorphy & Mesomorphy & Ectomorphy \\
\hline Mapuche & 3.9 & 4.1 & 2 \\
No-Mapuche & $4.1^{* *}$ & $4.3^{* *}$ & $2.4^{*}$ \\
\hline
\end{tabular}

$*_{p} \leq 0.05 ; * * p \leq 0.01$

\section{somatocarta}

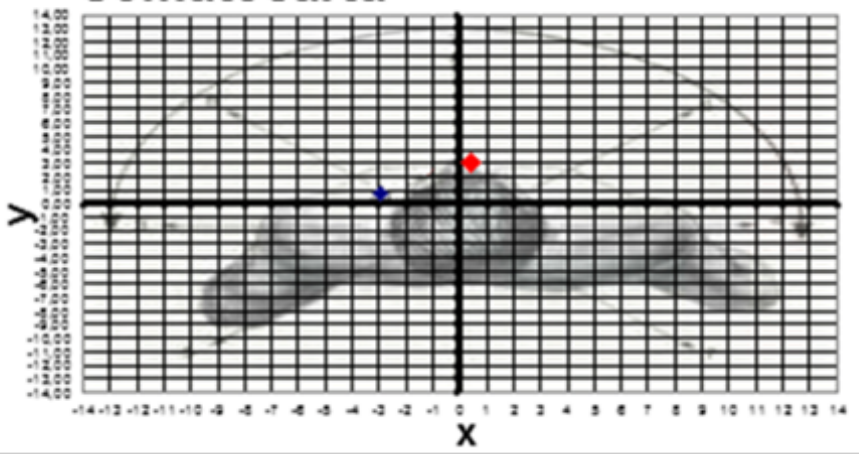

Figure 3 Somatotype in I2year-old Mapuche and non-Mapuche children.' DDS: $2.43 ; \mathrm{P} \leq 0.05$.

Mapuche; Non-Mapuche

\section{Discussion}

The results obtained in this study have contrasted with those corresponding to other human groups previously studied with the same methodology. The result of the Somatotype analysis indicates that the Endomorphic factor (linked to the relative presence of adipose tissue), its classification corresponds to moderate (3 to 5 according to qualitative classification), Mesomorphic factor (skeletal muscle development), its classification corresponds to moderate (3 to 5 according to qualitative classification), the Ectomorphic factor (relative slenderness), its classification corresponds to low. This classification, compared to the studies carried out by Silva et al., ${ }^{14}$ shows similar results in relation to the non-Mapuche population, if we compare the results of the Mapuche ethnic group with the study carried out by Arcay et al. ${ }^{15}$ To the Huilliche Ethnicity, we find that the classification is similar since both groups have the same somatotype classification (Mesoendomorphs). The results of this study are similar to the present study, which allows comparisons with the sample of the Mapuche ethnic group, indicating that they behave in a similar way in the characteristics of the Mapuche ethnic group. ${ }^{16}$ Nutritional status and somatotype. This indicates that the tendency of the nutritional status and somatotype of the previous studies carried out in Chile is maintained, in which the Mapuche population presents a mesoendomorphic somatotype. The somatotype of the non-Mapuche population is indicative of a higher content of adipose tissue over muscle and linearity, a condition that is present in the three groups studied.

When comparing by group, there are significant differences in endomorphism in favor of non-Mapuche and in Mapuche Mesomorphy. Ectomorphy was found to be greater in the Mapuche. However, no significant differences were found when comparing somatotype components among ages. Unlike the studies of ${ }^{2,17}$ in which somatotype modifications are observed among different ages.

Research at the international level yields results that are opposite to those found in the present research, by contracting somatotypes among ethnicities. ${ }^{4,18}$ Kagawa et al. $^{4}$ found differences when comparing Caucasian Australian children with Aboriginal Australians, being classified as monomorphic Caucasians and Aboriginal as endomesomorphic. The research carried out by Marrodán et al. ${ }^{18}$ Showed differences in somatotypes when comparing Mexican children and young people; The children of the Federal District and Lomas de la Estancia were classified as mesoendomorphs, while the inhabitants of Chontales were classified as mesoectomorphs, a situation that differs from the results found in the present investigation. Differences among groups of different ethnicities deserve special attention, due to the genetic load and the geographical context in which they are developed and the impact of policies that encourage different forms of ethnicity in social, health and education issues.

\section{Conclusion}

It is concluded that, considering the observed differences, the somatotype classifies the Mapuche and non-Mapuche children as "endomesomorphs" at the age of 10years and for the other age groups the classification was mesoendomorphic for the school Mapuche and endomesomorphic for the non-Mapuche Mapuche.

\section{Acknowledgements}

The authors should thank the principals of public education institutions, as well as the total number of students who participated in the present investigation.

\section{Conflict of interest}

Author declares that there is no conflict of interest.

\section{References}

1. Carter J, Ross WD, Duquet W, et al. Advances in somatotype methodology and analysis. American Journal of physical anthropology. 1983;26(1):193-213. 
2. Carter JL, Heath BH. Somatotyping: development and applications. UK: Cambridge University Press; 1990. 503p.

3. Alvero Cruz José Ramón, Giner Arnabat Lluis, Alacid Cárceles Fernando, et al. Somatotipo, masagrasa y muscular del escaladordeportivoespaño de elite. International Journal of Morphology. 2011;29(4):1223-1230.

4. Kagawa M, Byrne N, King N, et al. Etnics differences in body composition and anthropometrics characteristics in Australian Caucasian and urban indigenous children. Br J Nutr. 2009;102(06):938-946.

5. Goulding A, Taylor RW, Grant AM, et al. Waist-to-height ratios in relations to BMI z-scores in three ethnics groups from a representative sample of New Zeland Children aged 5-14years. Int J Obes (Lond). 2010;34(7):1188-1190.

6. Nightingale C, Rudnicka A, Owen Ch, et al. Influence of adiposity on insulin resistance and glycemia markers among UK children of South Asian, Black African-Caribbean, and white European origin child heart and health study in England. Diabetes Care. 2013;36(6):1712-1719.

7. Wang X, Chevalot N, Monnier G, et al. Validation of a model-based motion reconstruction method developed in the Realman project. SAE transactions. 2005;114(7):873-879.

8. Swan PD, McConnell KE. Anthropometry and bioelectrical impedance inconsistently predicts fatness in women with regional adiposity. Med Sci Sports Exerc. 1999;31(7):1068-1075.

9. Atilio Aldo AF, Pablo José LA, Fernando Javier RR, et al. Variables antropométricas y rendimientofísico en estudiantesuniversitarios de educaciónfísica. International Journal of Morphology. 2009;27(4):971-975.

10. Saitoglu M, Ardicoglu O, Ozgocmen S, et al. Osteoporosis Risk factors and association with somatotypes in males. Arch Med Res. 2007;38(7):746-751.
11. Hebbelinck M, Carter L, De Garay A. Body build and somatotype of olympic swimmers, divers, and water polo players. Baltimore: University Park Press; 1975. p. 285-305.

12. Ross WD, Wilson BD. A somatotype dispersion index. Research Quarterly. American Association for Health, Physical Education and Recreation. 1973;44(3):372-374.

13. De Rose EH, Pigatto E, De Rose RCF. Cineantropometría, Educação Física e Treinamento Desportivo. Rio de Janeiro: Ministério da Educação e Cultura. Fundação de Assistênciaao Estudante. 1984.

14. Silva H, Bruneau J, Reyno H, et al. Somatotipo e índice de masa corporal en unamuestra de adolescentes de ambos sexos de la ciudad de Temuco, Chile. International Journal of Morphology. 2003;21(4):309-313.

15. Arcay, Montoya Ramón. Composición Corporal en Escolares de Ascendenciaindígena del Norte, Centro y Sur de Chile. Educaciónfísica Chile. 1999;7(248):26-30.

16. Martínez C, Silva H, Collipal E, et al. Descripción del Somatotipo e IMC en unaMuestra de Adolescentes de Colegios Municipalizados de la Ciudad de Temuco-Chile. International Journal of Morphology. 2008;26(3):653-657.

17. Gaur R, Singh RP. Age differences in somatotypes of Garhwali males 17-60years of age. Am J Hum Biol. 1997;9(3):285-290.

18. Marrodán MD, Aréchiga J, Moreno Romero S. Cambios somatotípicos Durante el Crecimiento en población Mexicana masculina. Antropo. 2001;1:43-50. 